Список литературы:

1. Золотницкий В.А. Автомобильные газовые топливные системы. АСТ, Астрель, Хранитель. 2007.

2. Лиханов В.А., Деветьяров Р.Р. Применение и эксплуатация газобаллонного оборудования. Киров: Вятская ГСХА, 2006.

\title{
О совершенствовании конструкции келли-штанги
}

\author{
Дмитриев Г.Е., студент, \\ Северо-Восточный федеральный университет, \\ 2. Якутск \\ E-mail: ng.timofeev@s-vfu.ru
}

Научный руководитель: к.т.н., доцент Тимофеев Н.Г.

Учитывая тенденции увеличения объема шурфопроходческих работ при разведке россыпных месторождений полезных ископаемых, актуальность совершенствования техники и технологии этих работ значительно возрастает для геологоразведочных организаций страны. В первую очередь это касается изыскания высокопроизводительных и безопасных способов сооружения горных выработок: бурения скважин большого диаметра, шурфо-скважин и т.д.

Бурение шурфо-скважин (большого диаметра) при разведке россыпных месторождений в условиях криолитозоны из-за преобладания осложненных горногеологических условий (валунно-галечниковые отложения) в основном осуществляется ударно-канатным способом. Однако, учитывая низкое качество и достоверность геологической информации, получаемой при бурении скважин ударно-канатным способом, существует вероятность искажения данных разведуемого месторождения [1].

В этом направлении, одной из приоритетных задач совершенствования технологии бурения скважин большого диаметра (шурфо-скважин) в осложненных горно-геологических условиях представляется применение комбинированного (ударновращательного) способа бурения с использованием кластерных пневмоударников (объединение нескольких пневмоударников), который позволит повысить производительность труда и обеспечить качественный отбор пробы.

В настоящее время существует большое количество различных самоходных высокопроизводительных буровых установок зарубежного и отечественного производства для бурения технических скважин большого диаметра в различных горно-геологических условиях. Большинство буровых установок предназначены для работы с пнемоударными устройствами.

Как показывает практика, использование традиционных пневмоударников (кластеров) при бурении разведочных скважин большого диаметра, сопряжено рядом проблемных факторов. Это в основном спуско-подъемные операции тяжелой техники, наращивание става буровой колонны, разгрузочные работы которые выполняются с большой долей ручного труда. 
С целью оптимизации выше обозначенных факторов, рекомендуется применять в геологоразведке современную буровую установку, оснащённую технологией келлиштанги [2].

Телескопическая келли штанга представляет собой механическое устройство для передачи усилия подачи и крутящего момента на породоразрушающий инструмент. Келли штанга состоит из нескольких (от двух до пяти) вложенных друг в друга буровых штанг, входящих в зацепления благодаря специальным замкам. Все операции со штангой келли производятся с помощью лебедки буровой установки и гидравлического вращателя, а дополнительное усилие подачи обеспечивается цилиндром подачи, перемещающим вращатель в вертикальной плоскости.

Использование келли штанги позволяет значительно сократить время на спускоподъемные операции. При использовании келли-технологии, благодаря плавным переходам внутренних штанг к внешним, исключается возможность потери выбуренной породы с бурового снаряда при подъемных операциях, тогда как в обычных буровых установках разъединения буровых штанг сопровождаются ударами, вызывающими высыпание разрушенной породы из бурового снаряда и снижение качества отбираемой пробы.

Для эффективной разгрузки из бурового снаряда выбуренной породы, необходимо, чтобы буровая установка была оснащена поворотной платформой. При такой конструкции буровой установки обеспечивается безопасность разгрузочных и вспомогательных работ, в которых существует вероятность попадания извлеченной пробы в скважину из бурового снаряда или при вспомогательных работах (замене породоразрушающего инструмента, устранении поломок бурового снаряда и т.д.), попадания посторонних предметов в скважину.

Однако, известные телескопические бурильные трубы не могут быть использованы для бурения геологоразведочных скважин с применением пневмоударных механизмов, т.к. не приспособлены для подвода рабочего агента (сжатого воздуха) к пневмоударному устройству на забое скважины. В практике применяются рукава высокого давления (РВД), спущенные по наружной части бурового става. Недостатком данного подвода является большая вероятность заматываться РВД к буровой колонне при поворотных действиях пневмоударника, что может привести к его обрыву, а также при таком подводе РВД возникает ограничение по глубине бурения скважины.

Для решения поставленной задачи предлагается для подачи рабочего агента (сжатого воздуха) к пневмоударному устройству с конструировать внутреннюю гибкую трубу высокого давления, с катушкой для обмотки гибкой трубы, см. puc.1.

Принцип действия данной конструкции основан на традиционной технологии келли-штанги блокирующего типа.

Процесс работы заключается в следующем: вращающий момент и усилие подачи передаются от внешней штанги 5 на внутренние штанги 3,4, при котором сила давления на буровой инструмент передается через специальные замковые соединения буровых штанг со вставками из твердого металла. При этом диаметр и глубина бурения скважины зависят от развиваемого вращателем 8 крутящего момента, длины используемой келли-трубы и высоты мачты буровой установки. 


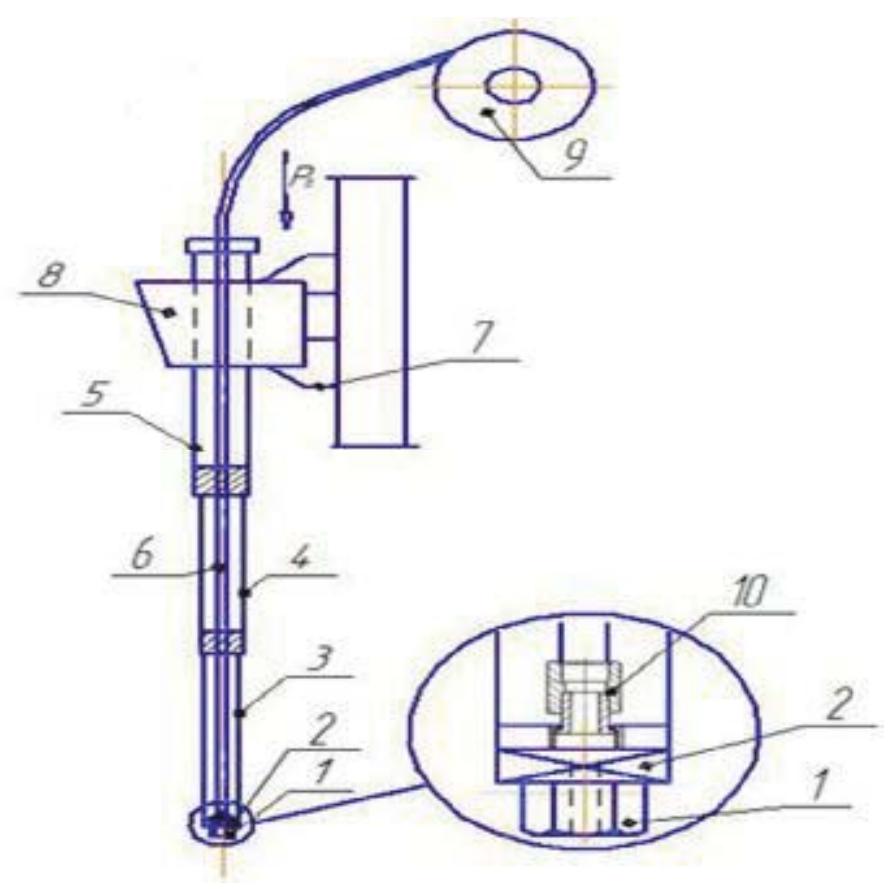

Рис.1. Конструкция усовершенствованной келли технологии

Пневмоударный буровой снаряд с породоразрушающим инструментом соединяется с хвостовиком 1 с амортизатором 2, в качестве которого для уменьшения вибрации и ударных нагрузок на келли-трубы может быть использовано, например, резиновое уплотнение или пружинный механизм. Осевое давление $P_{o}$ на всю колонну труб подается через каретки 7 буровой установки.

В процессе бурения, когда начинается углубка скважины, в определенный момент, верхний упор замкового соединения внутренней штанги 4 входит в контакт с ведущим захватом внешней трубы 5 и накладывается на него сверху. При дальнейшем углублении, выдвигаются только внутренние штанги до тех пор, пока предпоследняя внутренняя штанга 4 не упрется замком на нижнем конце самой наружной штанги 5. Так продолжается до полного телескопического выдвижения буровой колонны.

По мере углубления скважины при встрече породоразрушающего инструмента с крупными валунами, когда появляется необходимость бурения ударно-вращательным способом, подключается пневмоударное устройство посредством включения компрессора для нагнетания и подачи рабочего агента по внутренней гибкой трубе высокого давления 6, которая разматывается из катушки 9 буровой установки. Гибкая труба 6 соединена с хвостовиком бурильной трубы посредством герметичного поворотного соединения 10. При подъеме телескопической бурильной трубы труба 6 обратно наматывается на катушку 9.

После того, как породоразрушающий инструмент преодолеет крупные валуны, компрессор выключается и процесс бурения продолжается традиционным вращательным способом.

Преимущества использования в производстве заявляемого устройства:

- пневмоударный буровой снаряд с породоразрушающим инструментом намного повышает эффективность проходки по мерзлым валунно-галечниковым отложениям, что характерно в условиях криолитозоны; 
- за счет использования сжатого воздуха, достигается снижение себестоимости 1 м проходки скважины и расширяются возможности использования устройства в труднодоступных районах;

- повышается качество отбираемой пробы;

- устройство может заменить существующую технологию разведки россыпных месторождений полезных ископаемых, при этом достигается повышение производительности труда.

\title{
Список литературы:
}

1. Брылин В.И. Бурение скважин специального назначения: учеб. пособие/ В.И. Брылин. - 3-е издание. Томск: Изд-во ТПУ, 2009. - 255с.;

2. Грабчак В.Л. Возможности применения установок, использующих технологии келли штанг для бурения шурфов и скважин большого диаметра при геологоразведочных работах // Записки Горного института. Т.170. Часть 2. СПб., 2007. C. 59-63.

\section{Огранка ювелирной вставки из муассанита}

\author{
Егоров Ф.Д., студент, \\ Северо-Восточный федеральный университет, \\ 2. Якутск \\ E-mail: sakhapeja@mail.ru
}

Научный руководитель: доцент Федотова М.А.

Муассанит в ювелирном деле используют относительно недавно, порядка 20 лет всего. Этот камень обладает выдающимися оптическими свойствами [1]. Для раскрытия его красоты в виде ограненной вставки требуется рассчитать параметры его огранки. В связи с этим целью данной работы является вычисление параметров «идеальной» огранки для муассанита.

Для многих ювелирных камней стандартом огранки является «бриллиантовая» огранка. Круглая огранка изначально имела 17 граней. Сейчас такую огранку делают для камней с массой от 0,003 до 0,01 карат. Позже были разработаны более сложные формы огранки - двойная и тройная. В двойной огранке делали 16 граней с двух сторон, а в тройной, или полной бриллиантовой огранке - 24 снизу и 34 сверху. Полная бриллиантовая огранка была разработана еще в XVII веке. Такая огранка создает оптимальные условия для полного внутреннего отражения и дисперсии света в алмазе. Потерпев с тех пор массу изменений, идеальная огранка была рассчитана Марселем Толковским. На этом совершенствование круглой огранки не остановилось, и были предложены другие его вариации. Например, огранка Эпплера. Огранка Эпплера была получена путем измерения уже ограненных алмазов, бриллиантов, с наилучшими показателями блеска и игры света [2].

При идеальной огранке камень проявляет свою наилучшую «игру», зависящую от показателя преломления камня, угла полного внутреннего отражения и его дисперсии. Автор идеальной огранки бриллианта, Марсель Толковский, в своих 